\title{
Studies on standardization and physico-chemical properties of Amaranth flour cakes
}

\section{RUPALI SHYAM SHINDE AND RITA SINGH RAGHUVANSHI}

Received: 19.05.2015; Revised: 03.10.2015; Accepted: 12.10.2015

See end of the paper for authors' affiliations RUPALI SHYAM SHINDE Department of Foods and Nutrition, College of Home Science, G.B. Pant University of Agriculture and

Technology, Pantnagar, U.S. NAGAR (UTTARAKHAND) INDIA

(Email : rupali10shinde@gmail.com
ABSTRACT : Egg cakes were prepared by using different levels of amaranth flour into refined wheat flour with the constant level of whey protein concentrate by method of U.S. Wheat Associates in 1983. Physical characteristics of amaranth grains and functional properties of flour were studied. It was found that seed weight, volume are less than other cereal as Amaranth seeds are tiny and lighter in weight. The water absorption and fat absorption capacity of variety PRA-3 was recorded as 1.6 per $\mathrm{g}$ of flour and $1.9 \mathrm{ml} / \mathrm{g}$ flour. Volume and specific volume of control cake was higher than the amaranth flour incorporated cakes. There was significant difference between volume index, symmetry index and uniformity index of control and 40 per cent amaranth flour cake. The overall acceptability scores of 40 per cent Amaranth flour cake was maximum and more than control for cakes (8.3).

KEY WORDS: Cakes, Amaranth flour, Wheat flour, Whey protein concentrate, Physical charateristics, Physical indices

- HOW TO CITE THIS PAPER : Shinde, Rupali Shyam and Raghuvanshi, Rita Singh (2015). Studies on standardization and physico-chemical properties of Amaranth flour cakes. Asian J. Home Sci., 10 (2) : 285-289. 